\title{
Formation of Proactive Strategies of Chinese Private Equity Funds in the Russian Corporate Control Market
}

\author{
Maria M. Musatova, Larisa I. Lugacheva \\ and Elena A. Solomennikova \\ Institute of Economics and Industrial Engineering \\ of SB RAS \\ 17 Akademika Lavrent'eva, Akademgorodok, \\ Novosibirsk, 630090, Russia
}

Received 01.03.2019, received in revised form 01.04.2019, accepted 09.04.2019

The article discusses the boundaries and contours of the possible institutional behavior of private equity funds (PEFs) in the Russian Federation in modern conditions. It analyzes the transformation of PEF sectoral interests in the Russian assets of non-public companies in the period of economic instability. Besides, it gives a relevant assessment of changes in the regional aspects of interaction between PEFs and recipient companies from Russia against the background of sanctions and import substitution, as well as private equity cycle. The article presents the modern metrics of Chinese PEFs and a multi-level monitoring of existing Chinese PEF projects in the Russian economy. It also analyzes the effects of multi-agent relations of PEFs and target companies in Russia against the background of a gradual recovery of the country's economic growth. The article discusses the current and preferred format for the participation of investors in the PE market in the context of the adaptation of the Russian economy to the sanctions regime. It identifies the factors affecting the prospects and dynamics of the development of Chinese PEFs with an investment mandate for Russia and discusses the mechanisms of institutional support for expanding the presence of Chinese PEs in the Russian market for corporate control.

Keywords: private equity, private equity funds, investment, institutional environment.

The publication is prepared within the project XI.172.1.3 (No. AAAA-A17-117022250130-8) "Theory and methodology of strategic management of the high-tech business development as the basis of new industrialization" according to the research plan of the IEIE SB RAS and project XL172.1.1 (No. AAAA-A17-117022250132-2) "Integration and interaction of sectoral systems and markets in Russia and its eastern regions: constraints and opportunities".

(C) Siberian Federal University. All rights reserved

* Corresponding author E-mail address: esolom46@mail.ru

ORCID: 0000-0001-8325-5284 (Solomennikova); 0000-0002-5544-5539 (Musatova); 0000-0002-9675-1567 (Lugacheva) This work is licensed under a Creative Commons Attribution-NonCommercial 4.0 International License (CC BY-NC 4.0). 
Research area: world economy.

Citation: Musatova, M.M., Lugacheva, L.I., Solomennikova, E.A. (2019). Formation of proactive strategies of Chinese private equity funds in the Russian corporate control market. J. Sib. Fed. Univ. Humanit. soc. sci., 12(4), 660-677. DOI: 10.17516/1997-1370-0415.

\section{Introduction to the research problem}

In the recent 30 years, the private equity (PE) industry has become an important sector in the global financial services market. Its role that is a bigger support for innovation, business firms, their growth, employment of the working population, compared with other financial sectors is becoming more significant.

The development of corporations and enterprises with the participation of PE funds in Russia and around the world is growing. Many of the largest transnational corporations have become such by attracting a special strategic partner and investor, namely a private equity fund. Examples of such corporations include Intel, Apple Computers, Cisco Systems, Microsoft, Sun Microsys-tems, Compaq Federal Express Corp., Oracle Corp., Yahoo!, Amazon.com. Interaction with external institutional investors is one of the most common methods of development, which even very successful companies now resort to. Decisions made in this area are strategic and their importance is great both for the enterprise and, ultimately, for the entire economy of the country.

Over the past decades, most studies have not focused on the structural characteristics and factors of the PE industry, but considered it as a whole (developed and emerging markets). Among them are the works of the famous researchers Farag (Farag et al., 2004), La Porta (La Porta et al., 1997), Desai (Desai et al., 2006), Gompers (Gompers, Lerner, 2000), Lerner (2011)).

In the period of financial instability, the imposition of sanctions, the study of the dynamics and structural characteristics of PEFs in emerging markets is becoming urgent.

The trend in the dynamics of the PE sector in the Russian Federation, where before the imposition of sanctions, PEFs of developed countries had prevailed, began to change its direction in 2017: a reversal towards growth began. In 2018, its strengthening was supported by new fundamental factors in the Russian economy, as well as the growth of its international ratings and indices: the country rose in the economy global competitiveness ranking from the $45^{\text {th }}$ line up to $43^{\text {rd }}$ one and became the best among the countries of Eurasia ${ }^{1}$. This index measures the readiness of countries for the fourth

Global Competitiveness Index (GCI) is released by the World Economic Forum (WEF) in conjunction with the Eurasian Institute of Competitiveness and Strategy Partners consulting company. This is a result of macroeco- 
industrial revolution (Rossiia uluchshila pozitsii..., 2018); The international rating agency Standard \& Poor's upgraded Russia's rating from speculative $B B+$ grade to the investment $B B B$ - grade, while the outlook is negative (S\&P..., 2018). Within the framework of import substitution, to which, after the imposition of the sanctions regime by the West, Russia has been oriented since 2014, it is possible for local producers to attract foreign investors to PE in the short term. Additional opportunities for investors may also arise through the privatization process.

The state of the Russian economy in 2018, a reasonable fiscal policy, low inflation, a predictable ruble exchange rate and a reduced dependence on external market conditions in the near future may give grounds for rating agencies to increase their rating. Against this background, the PE sector in the Russian Federation has once again become very attractive for Asian investors.

\section{Conceptual basis of the study}

Few problems of economic theory and practice cause more heated debates than problems of investment of PE funds in non-public companies with high development potential. Opposite points of view of the feasibility and effectiveness of such investment projects of PE funds collide: some people regard them as an important source of improving the performance of portfolio companies; others consider them to be only a way for funds to get excess returns obtained through the sale of a company's assets and an increase in its debt burden.

The fundamental works on the comparative effectiveness of various forms of organization of corporate control are the numerous publications of M. Jensen (Jensen, 1998). They explore the effectiveness of the impact of $P E$ funds as an investor on a company's operations. His main hypothesis, further confirmed by empirical work, was as follows: the activity of PE funds leads to the emergence of more efficient companies in various product markets.

M. Jensen believed that the acquisition of substantial corporate control by PE funds in companies allows the fund to conduct financial, managerial and operational restructuring of portfolio companies and thus increase the efficiency of companies and increase their economic value; to build the right schemes of management motivation

nomic stability: GDP is growing moderately, inflation has significantly decreased, public debt has remained low for a long time. WEF identifies the size of the domestic market, human capital and the level of development of the basic "digital infrastructure" as the strengths of Russia. The weaknesses are associated with the development of the financial sector, regulatory restrictions and competition in certain sectors of the economy. 
in portfolio investments. According to M. Jensen, the activity of private equity funds leads to more efficient companies.

M. Jensen's hypothesis was tested by a number of authors. One of the most recent works in this area is the study of Kaserer (Kaserer, 2012), performed on grounds of the data from 15 European countries from 1990 to 2011. Using the method of factor analysis to assess the profitability of the transaction and the contribution of certain aspects of the active management of the fund, Kaserer revealed that the $3 / 4$ IRR transaction can be attributed directly to the contribution of the operational and strategic aspects of the activities of the funds aimed at increasing the efficiency of the company.

Using a sample of PE funds in 22 European countries in 2002-2007, Badunenko, Baum and Schäfer (Badunenko et al., 2010) conducted an assessment of the panel data on the dynamics of return on assets. It was revealed that the presence of a PE fund among the company's shareholders has a slight negative effect on the profitability of assets. However, if the fund had been present in the company's share capital during 6 previous years or longer, the effect of its work became positive.

Based on a sample of data on 147 companies that were supported by private equity funds and conducted an IPO period of 1980-2006, Katz (Katz, 2009) showed that companies have more reliable indicators of profitability and higher quality of financial statements. Invested companies demonstrate higher stock price indicators than the control group. These effects are achieved due to the professionalism of the investor and vigilant monitoring of the company.

In recent years, some attempts have been made to study the process of investing PE funds in an unstable economy and emerging markets (through the example of Central and Eastern Europe (CEE). These results may be useful to government agencies for the possible activation of economic policies to stimulate PE industries in Russia.

\section{Methodology}

Decisions made by PEF about investing are strategic and are reflected throughout the whole chain of multi-agency relations. In this regard, PE analysis methodology should be based on scientific principles, such as historicism, objectivity, consistency, complexity, variance (alternativeness), transparency, unity of theory and practice.

The principle of historicism requires studying the historical reasons for the emergence of private equity funds in the Russian context; the behavior of the private equity sector during the business cycle; identification of the stages of its formation in the Russian Federation, the conditions of development in a changing geopolitical environment. 
The principle of objectivity implies reliance on facts and consideration of historical phenomena from the point of view of objective laws. As a result, objective reasons can be identified that contribute to the strengthening of the trend towards the design of processes and the formation of a special system of interaction - "state-corporations" in terms of direct investment.

The principle of consistency means considering private equity funds in Russia as a system, identifying a certain set of its elements, establishing, classifying elements, which include a typology of private equity funds in the Russian Federation, systematizing agents of the Russian corporate control market, restrictions and problems on the development of private equity funds, etc.

The principle of complexity suggests that private equity funds in Russian companies should be considered in the relationship of all elements and external relations. With this in mind, a comprehensive assessment of the performance of PE funds can be obtained based on the results of econometric modeling.

The principle of variation (alternativeness) is associated with the search for predictable options for the behavior of private equity funds in Russian conditions and the validity of several options for constructing econometric models.

The principle of transparency implies the possibility for independent experts to gain access to the methodology and methods of calculation, to assess the performance of private equity funds and the processes of conducting economic and mathematical modeling.

The principle of unity of theory and practice allows practical testing of theoretical approaches to study the positive effect of the active management of Russian companies by PE funds.

The above principles were used in the generalization of disparate materials on the theory and practice of transformation of the behavior of PE funds in Russia with the aim of identifying a number of significant patterns in different periods of market transformations (1992-1998; 1999-2004; 2004-2008; 2009-2013; 2014-2018). In the course of research in the development of the Russian PE market, the following stages and their features were highlighted.

Stage of formation of the Russian PE market (1992-1998). The impetus to the emergence and subsequent active dynamics of growth of this market was privatization. The appearance of large foreign funds, the launch of the first Russian funds with the support of the EBRD (European Bank for Reconstruction and Development). Establishment in 1997 of the RAVI (Russian Association of Venture Investments). 
Stage of redistribution of property in Russia (1999-2004). The emergence of a new class of investors, various types of Russian PEs (including the creation of PE captive funds).

Stage of stable growth (2004-2008). High rates of development of the economy of the Russian Federation, institutional changes led to an increase in investment interest from foreign PE funds. The main leaders of that period were oil and gas companies and the electric power industry. The rapid growth of emerging markets and the overall political stability of economies in 2004-2008 created favorable conditions for the development of companies in these markets. The presence of attractive companies for investment, the possibility of diversifying the portfolio, as well as a high return on investment of PE. Despite the global recession that began in August 2008, many PEFs continued to increase their presence.

Stage of commitment to global smart-capital and government support (2009-2013). PE operating in the Russian market was provided with a wide access to global smart capital (first of all, EBRD and IFC), the creation of Russian PEF in 2011.

Stage of reformatting the PE market (2014-2018). Strengthening the influence of the state, both in the domestic and international markets. There was a discontinuation of financing of investment projects by international organizations and there was a gradual withdrawal of this class of institutional investors from the Russian PE market. For the first time, sovereign funds of Arab and BRICS countries came to Russia, strengthening the PE position from China.

The paper uses a political economy approach that implies a methodological framework for logical analysis and modern tools of institutionalism. The tasks of the paper were solved on the basis of a set of systemic methods: structural-logical and factor analysis, revealing the consistency of the Russian PEF state policy in investment processes and the existing market environment. The proposed material applied methods of systematization, classification, grouping, comparison. The factor analysis of the conditions for the revitalization of Chinese PEFs is based on stylized facts and casestudy methods.

Problem statement: a specific problem that is considered directly by the authors in the paper follows from the Introduction.

The subject of research in this paper is the institutional environment of Chinese PEFs in Russia and its regions in the context of the ongoing sanctions regime.

The purpose of this paper is to study the characteristics of the behavior and functioning of Chinese PEFs in the Russian Federation during the transition to the model of economic growth. 
The study of the institutional configuration of Chinese PE activities in Russia seems to be useful for developing strategic decisions and policies for encouraging nonpublic manufacturing companies, an infrastructure profile at the state level. Although a number of definite successes have been noted in the implementation of the strategy for changing the regional focus of working with foreign PEFs, there are still some accumulated problems.

\section{Discussion}

The improvement of macroeconomic conditions, the stabilization of oil prices and the adaptation of the Russian economy to the sanctions regime increase investor interest in Russian assets. The recession of the past four years and the sanctions have devalued the value of the assets of non-public Russian companies and by 2018 their current valuation had become significantly lower compared to their counterparts in emerging markets. The aspirations of private equity funds (PEFs) to find more efficient niches for free capital, as compared to risk-free bank deposits, force them to constantly monitor the situation in the financial markets.

Private equity unlike portfolio investments in securities is not designed for short-term financial benefits, but for long-term partnership in the development of non-public companies, while funds are invested in real assets of companies, such as equipment, infrastructure, real estate, technology, as well as intellectual property and staff training.

Institutional behavior of PEFs in the Russian Federation is regulated by the Federal Law No. 156-FZ “On Investment Funds", which establishes stricter activity standards in terms of financial reporting and independent auditing compared to the United States and Europe. Institutional barriers in the activities of PEFs in the Russian Federation are connected with the incompatibility of the Russian legislation on property with the legislation of European countries and the United States. In this regard, PEFs in order to maximally protect the interests of their shareholders, strive to act within the jurisdiction of English law and use offshore structures.

Federal legislation monitors and regulates the sectoral focus of the direct financing process of PEFs, while the Ministry of Economic Development is responsible for formulating government policy on investors. Over the past ten years, the provisions relating to PE funds have been repeatedly revised. For example, restrictions were imposed on the participation of foreign capital in such sectors as natural gas production, forestry, and transportation services. The complete ban was imposed on the financing 
of the funds of enterprises associated with the defense industry and national security registered abroad (Gritsenko, 2016).

The behavior of PEFs in Russia is influenced by the cyclical return on alternative investments. Macroeconomic problems, the imposition of sanctions, a cyclical decline in PE as a class of investments in emerging markets have reduced Russia's attractiveness for private equity funds in 2014-2017. During this investment pause, the PEFs were forced to reformat their behavior in order to enter a new cycle of the Russian market with changed strategies (Table 1).

Table 1. Changing REF strategies in the Russian market

\begin{tabular}{|l|l|}
\hline \multicolumn{1}{|c|}{$\begin{array}{c}\text { PEF strategies of a previous cycle } \\
\text { (2007-2013) }\end{array}$} & \multicolumn{1}{c|}{$\begin{array}{c}\text { PEF strategies of a new cycle } \\
\text { (since the end of 2017) }\end{array}$} \\
\hline $\begin{array}{l}\text { Acquisition of controlling stakes, which meant the } \\
\text { removal of existing shareholders }\end{array}$ & $\begin{array}{l}\text { Acquisition of minority stakes, retaining } \\
\text { existing shareholders and management }\end{array}$ \\
\hline $\begin{array}{l}\text { Buy bad, create good logic dominance: fund } \\
\text { managers will be able to rebuild any enterprise } \\
\text { and manage it better than its creators or industry } \\
\text { managers }\end{array}$ & $\begin{array}{l}\text { Investments only in market leaders, which } \\
\text { significantly increases the possibility of IPO; } \\
\text { PEFs form a portfolio of assets for a specific } \\
\text { idea }\end{array}$ \\
\hline $\begin{array}{l}\text { Failure to understand hidden problems, lack } \\
\text { of ability to engage in dialogue with company } \\
\text { management and other shareholders }\end{array}$ & $\begin{array}{l}\text { Small-cap and mid-cap companies - Steady } \\
\text { Growth Drivers }\end{array}$ \\
\hline $\begin{array}{l}\text { 5-6 year fund exit plans } \\
\text { Fund managers were bankers, MBA graduates } \\
\text { with no work experience, medium-term investment } \\
\text { bankers, analysts, marketers and non-professionals }\end{array}$ & $\begin{array}{l}\text { Fund managers should be the world's best } \\
\text { industrial teams }\end{array}$ \\
\hline
\end{tabular}

Compiled by the authors.

The interest in non-public companies that has been resurging in the PE market since 2017 inevitably raised the question of attracting financial resources to capitalize PEFs for a long period of time in the context of the termination of support from the organizations of the World Bank Group.

Experts say, on the one hand, there is not enough "free" money in bank accounts in Russia, on the other hand, there are many profitable projects that could benefit society, but it is very difficult to find financing for them. Potential capitals and underfinanced projects, as a rule, cannot find a consensus with each other on such three parameters as return periods, level of profitability and acceptable risks. It should be noted that in recent years, the changing geopolitical conditions, the instability of the global economy 
have lowered sights of both sides in two of these parameters. However, reducing and eliminating risks remains a serious problem.

The activities and format of PEF behavior are associated with a number of risks: strategic, corruption, criminal risks, which are characteristic of high-yield markets in general. The strategic risk is that the interests of foreign investors are concentrated in the Russian Federation in a narrow range of industries, and this contributes to increasing the economic risks in the long term. Increased risks for PEFs in Russia are associated with the possibility of regulatory intervention in the activities of entire industries or individual companies, as well as the relatively low protection of minority shareholders in the Russian market as a whole.

In terms of developing PE markets, experts note the alternation of cycles with high profitability and attractiveness of investments and periods of capital outflow to the markets of developed countries as occurs in any financial market, when the yield in developing markets showed a falling trend. A change of cycles in the PE market is accompanied by a change in investment opportunities. In Russia, the cycle with high profitability of private equity funds (PEFs) in 2007-2013 was replaced by an investment pause: from 2014 to the second half of 2017, there was an outflow of PEF capital to the markets of developed countries.

The ban for companies from EU countries to invest in infrastructure projects (transport, telecommunications and energy projects) and in the extraction of oil, gas and mineral raw materials, to supply equipment, to provide financial and insurance services to enterprises of these industries has led to changes in the sectoral interests of Western PEFs in Russian assets (Table 2). Against this background, two groups of assets have become attractive for foreign PEFs: assets that have a production base in Russia, but that can generate cash flow in foreign currency, as well as assets that operate in industries close to the end user (food processing, pharmaceuticals) and production of high-tech products.

Table 2. Changing the sectoral priorities of overseas PEFs in the Russian market

\begin{tabular}{|l|l|}
\hline \multicolumn{1}{|c|}{ Previous cycle (2007-2013) } & \multicolumn{1}{c|}{ New cycle, starting from 2017} \\
\hline $\begin{array}{l}\text { The ICT sphere (Internet, financial } \\
\text { technologies) finance, transport, production } \\
\text { of fuel and raw materials, energy, retail } \\
\text { chains, consumer sector of the Russian } \\
\text { Federation, logistics, real estate }\end{array}$ & $\begin{array}{l}\text { ICT sphere (new services, digital economy) teleme- } \\
\text { dicine, B2B sector services, agriculture, agribusiness, } \\
\text { pharmaceuticals, medicine, education, consumer } \\
\text { sector of the Russian Federation, separate food } \\
\text { product groups, hospitality, commercial real estate }\end{array}$ \\
\hline
\end{tabular}

Compiled by the authors. 
According to Russian Venture Capital Association, in the Russian PE market, such sectors as retail, telecommunications, and banking sector have reduced their growth rates since 2013: a fall in consumer demand and real incomes of the population had a very negative effect on the expansion of retail chains; the density of loans provided to the population of Russia is very high, and the situation in banks with "bad loans" is not the best possible; The former format of communication services and the Internet has reached its top line (Overview..., 2018).

Both foreign PEFs and Russian PEFs view the current situation as attractive, since a very low threshold for entry into the capital of Russian non-public companies has been formed. Their interests are focused on agricultural projects, industrial projects, infrastructure, IT, healthcare, biotechnology (Glorax Group..., 2017).

At the same time, foreign investors are warned about significant restrictions and controls in the military and nuclear industry, media, mining and energy, agriculture, port and airport infrastructure, and to a lesser extent in finance and insurance. Both the fishing industry and mining of precious stones and metals in the Russian Federation are practically closed to investors (Krasnushkina..., 2017).

In the future, international private equity funds, having a large investment potential, can become a full-fledged source of capital for Russian entrepreneurship and complement the banking system. In our opinion, the revival of the Russian PE market will take place against the background of the cessation of the general business downturn, the positive dynamics of key macroeconomic indicators and the return to Russia of both international economic organizations and global private equity funds.

According to the statistics, one of the key players in the global investment market is China. Russia was and remains in the list of its priority areas. Strategic investors from China are traditionally interested in the spheres of energy, metallurgy, commercial real estate, the transport and tourism industry, high technologies, as well as the infrastructure sector (projects for the construction of roads, ports and energy projects) based on private government partnership with significant government support. Experts estimate the potential volume of investments from China to industry and commercial real estate of the Russian Federation at several billion dollars. Also, according to studies, $57 \%$ of Chinese companies plan to increase and expand their investment portfolio (Glorax Group..., 2017).

Asian investors, which are the largest investment groups in China, are actively investing in commercial real estate in the largest cities of the Russian Federation such as Moscow and St. Petersburg. PE companies and funds from China closed a number 
of large transactions in 2017 and thus turned out to be the main and only foreign investors in the commercial real estate market of Moscow since the beginning of 2017. Thus, in the first half of 2017, the volume of investments in Moscow's commercial real estate from Chinese investors was valued at $\$ 170$ million (Glorax Group..., 2017). Chinese investment companies are negotiating with A. Birzhin's Glorax Group PEFs regarding the implementation of joint projects in the Russian commercial real estate segment (office, warehouse and retail real estate) of the North-West Federal District.

At the beginning of the $21^{\text {st }}$ century, Russia and China occupied approximately the same positions in terms of the amount of funds mobilized by PEF, but by 2017 PE investments targeted at China had turned out to be hundredfold in comparison with the capital working with Russia (Table 3).

Table 3. The amount of funds raised by PEFs in the BRICS countries in 2002-2017, million dollars

\begin{tabular}{|c|c|c|c|c|c|c|c|c|c|}
\hline Country & 2002 & 2008 & 2011 & 2012 & 2013 & 2014 & 2015 & 2016 & Q3 2017 \\
\hline Brazil & 270 & 3363 & 6484 & 2080 & 639 & 3924 & 792 & 151 & 144 \\
\hline India & 142 & 6114 & 2669 & 2545 & 1017 & 1649 & 4142 & 3199 & 2092 \\
\hline China & 105 & 14185 & 21358 & 11173 & 11377 & 12450 & 11955 & 19717 & 7292 \\
\hline Russia & 100 & 591 & 262 & 575 & 601 & 317 & - & - & - \\
\hline South Africa & & 219 & 39 & 837 & 3 & 80 & - & 312 & - \\
\hline
\end{tabular}

Source: (EMPEA Annual Report 2015/2018).

In China, against the backdrop of a huge attraction of foreign PEFs for the period of 2002-2017, a powerful segment of domestic PEFs, which were ready to search and implement investment projects in Russia, formed. Geoeconomic strategies of China, the search for strategies for further growth based on the growth of domestic consumption form and adjust the institutional space for overseas expansion of Chinese investment (Table 4).

The strengthened state presence in the Russian private equity industry and the intensive functioning of the RPEF in the Asian region led to the emergence of a joint international private equity fund with the participation of the Russian Federation Industrial Development Fund, the Silk Road International Development Fund (SPIDF), Hong Kong, and the Center for Investment, Technology and Trade (Musatova, Lugacheva, 2018). The national priorities of the Russian state in creating this fund are to support domestic producers by attracting investors, speeding up the solution of the priority tasks of import substitution in the manufacturing sector, where many non-public recipient companies 


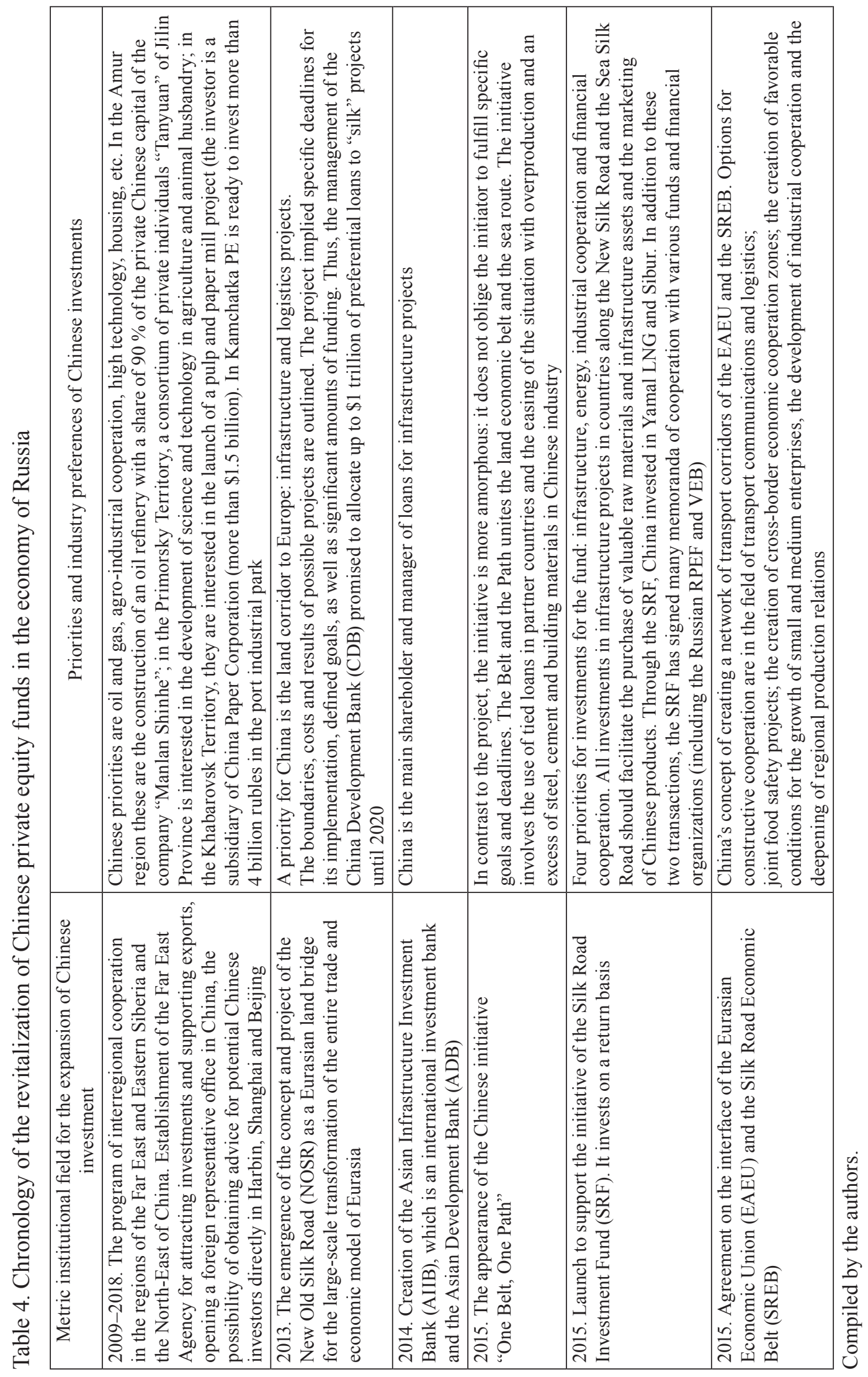


are concentrated, with an attractive market potential; financing of Russian enterprises. The multi-agency interests of Chinese PEFs are focused on the implementation of plans for aggressive development with minimal costs, building capacity to seize the market; on transition to stable leadership in priority sectors; purchase of problem assets; formation of joint PE funds, asset resale, and others. The Silk Road Development Fund will provide the first tranche of $\$ 300$ million for investment projects of the Industrial Development Fund, represented by medium-sized companies in the manufacturing sector. Additional funding from the Silk Road Development Fund in Russian projects (both in the form of a loan and in the form of entering into capital) will allow non-public companies to expand opportunities for exporting products to the Silk Road countries (more than 60 countries around the world), as well as to create technological initiatives to localize the world's leading manufacturing practices (Musatova et al., 2018).

\section{Conclusion}

To date, the institutional configuration of Chinese PEFs in the Russian market has its own characteristics.

1. Due to serious risks, Chinese projects and PEFs are primarily focused on cooperation with state institutions: RPEF and Vnesheconombank (VEB). Strategic investors from China have been traditionally interested in the sector of infrastructure projects (projects for the construction of roads, ports, energy projects) on the basis of a public-private partnership with significant state support.

2. The expansion of PEF activities led to the creation of a joint fund in RMB together with the RPEF and China Development Bank for investing in joint projects of up to $\$ 10$ billion. 30 projects are being studied in the field of retail, agriculture, food industry, real estate and pharmaceuticals (Uspeshnye investitsii..., 2016).

3. The emergence of a joint international PEF, which was created at the initiative of China to implement the concept of "One Belt and One Path". It combines projects of the Economic Belt of the Silk Road and the Sea Silk Road of the $21^{\text {st }}$ century. Participants include the RPEF, the Industry Development Fund (IDF) of the Russian Federation, the Silk Road International Development Fund, Hong Kong (SPIDF) and the Center for Investment, Technology and Trade (Sozdanie mezhdunarodnogo..., 2017).

4. PEFs of the largest investment groups in China are actively investing in Russian assets in various fields of activity.

Significant investment opportunities for Chinese PEFs in Russia are associated with a low level of labor productivity in the economy compared to developed PE 
markets and an enormous potential for raising it in many sectors and fields. Unlike Western PEFs, for which investment in many areas is "frozen" by the imposition of sanctions, Chinese PEFs are not limited in the range of their preferences. Experts estimate the potential volume of investments from China to industry and commercial real estate in the Russian Federation at several billion dollars. Also, according to studies, $57 \%$ of Chinese companies plan to increase and expand their investment portfolio (Krasnushkina, 2017).

New geopolitical conditions, changes in the structure of the global and Russian economies are forcing Chinese private equity funds to (Musatova et al., 2018), (Frolova, 2016):

- search for new industry growth points that meet the challenges of the time. Among them are agribusiness, hotel industry, logistics, infrastructure projects, etc.;

- actively use emerging opportunities to attract financial resources. The emergence of new international institutional investors, such as the New Development Bank, the Asian Infrastructure Investment Bank, the Bank of the BRICS and the dominant position of China in the statutory funds of these organizations allow Chinese investors to have a particularly wide access to the smart capital of these organizations;

- expand the regional focus of its presence in Russia, focusing on the rating of investment attractiveness.

The prospects for expanding the presence of Chinese PEFs in the Russian corporate control market are associated with the possibility of participating in the privatization of a number of Russian companies, as well as easing the internal restrictions on the acquisition of foreign assets for Chinese investors.

At the same time, Russian regulators are worried about the mutual openness of economies for foreign direct investment, so their relationship with Chinese investors will be directly related to the future liberalization of the Chinese economy. Since the end of 2016, Chinese investors have been facing obstacles inside the country, namely, the Chinese authorities have tightened control over capital outflows. Companies are recommended to refrain from buying foreign assets that are not related to their core business, and the creditworthiness of investors is being carefully checked.

\section{References}

Badunenko, O., Barasinska, N., Schäfer, D. (2009). Working Paper Are private equity investors good or evil? German Institute for Economic Research, No. 901 (DIW Berlin). Available at: http://hdl.handle.net/10419/29742 
Badunenko, O., Baum, C., Schäfer, D. (2010). Does the tenure of Private Equity investment improve the performance of European firms? Discussion papers. Boston College Working Papers in Economics. Available at: http://ideas.repec.org/p/boc/ bocoec/730.html

Chubais, A. (2016). Tekhnologicheskoe predprinimatel'stvo i global'nye tekhnologicheskietrendy. Otkrytaialektsiia[Chubais A. Technologicalentrepreneurship and global technological trends. Open lecture]. Available at: http://www.rusnano.com/ about/press-centre/first-person/20160411-fiop-otkrytaya-lektsiya-chubaisa (Accessed 04. 05.2018).

Cumming, D., Flemming, G., Schwienbacher, A. (2006). Legality and venture capital exits. In Journal of Corporate Finance, 12, 214-245.

Desai, M., Gompers, P., Lerner, J. (2015/2016). Institutions and entrepreneurial firm 1. Emerging Markets Private Equity Association EMPEA Annual Report. Available at: http://www.empea.org/about/annual-report/ (accessed 17.04.2018).

Dynamics: evidence from Europe, Harvard NOM Research Paper 03-59. (2006). Boston. In Harvard Business School NOM Unit.

Farag, H., Hommel, U., Witt, P. et al. (2004). The macroeconomic determinants of private equity investment economies: a comparative analysis of Eastern European and German Markets. In Venture Capital, 6, 257-282.

Frolova, I. Iu. (2016). Kitaiskii proekt «Ekonomicheskii poias Shelkovogo puti: razvitie, problemy, perspektivy» [Chinese project "Economic belt of the silk road: development, problems, prospects']. In Problemy natsional'noi strategii [Problems of national strategy], 5 (38), 47-68.

Glorax Group Andreia Birzhina vedet peregovory s kitaiskimi investorami [Andrey Birzhin's Glorax Group negotiates with Chinese investors] (2017). Available at: http://www.rosbalt.ru/business/2017/08/03/1635844.html (accessed 8.10.2017).

Gompers, P., Lerner, J. (2000). Money chasing deals? The impact of funds inflows on the valuation of private equity investments. In The Journal of Financial Economics, $55,281-325$.

Gritsenko, A. (2016). Rynok priamykh investitsii szhimaetsia [The private equity market shrinks]. Available at: https://finance.rambler.ru/economics/35629335-smirynok-pryamyh-investitsiy-szhimaetsya/ (accessed 8.12.2017)

Jensen, M.C. (1998). Specific and General Knowledge and Organizational Structure, Foundations of Organizational Strategy, Harvard University Press. In Journal of Applied Corporate Finance, 8, 4-18. Available at: http://ssrn.com/abstract $=6658$ 
Katz, S.P. (2009). Earnings Quality and Ownership Structure. The Role of Private Equity Sponsors. In The accounting review American Accounting Association, 84 (3), 623-658. DOI: 10.2308/accr.2009.84.3.623

Kaplan, S.N., Per, S. (2009). Symposium: Private Equity: Leveraged Buyouts and Private Equity. In Journal of Economic Perspectives, 23(1), 121-46б.

Kaserer, C. (2012). Return Attribution in Mid-Market Buy-Out Transactions New Evidence from Europe. Research Report Series, Center for Entrepreneurial and Financial Studies.

Krasnushkina, N. (2017). Kitaiskie investory gotoviat ekspansiiu [Chinese investors have been preparing for expansion]. Available at: https://www.kommersant. ru/doc/3379094 (accessed 28.04.2018).

La Porta R., Lopez-de-Silanes, F., Shleifer, A. et al. (1997). Legal determinants of external finance. In Journal of Finance, 52, 1131-1150.

Lerner, J. (2011). The Future of Private Equity. In European Financial Management, 17 (3), 423-435.

Musatova, M.M., Lugacheva, L.I., Solomennikova, E.A. (2018). Chinese private equity funds on the Russian market for corporate control: motives and industry preferences. In Sino-Russian global engagement models in the context of digitalization of social and economic processes: Proceed. International research and practical conf., Krasnoyarsk, Siberian Federal Univ., Ministry of Science and Higher Education of the RF, Association of Sino-Russian Economic Univ., 108-112.

Musatova, M.M., Lugacheva, L.I. (2018). Rossiiskie fondy priamykh chastnykh investitsii: novaia ekonomicheskaia i investitsionnaia real'nost' [Russian private equity funds: a new economic and investment reality]. In ECO, 2, 139-154.

Overview of the market of direct and venture investments in Russia in 2017. Available at: http://www.rvca.ru/rus/resource/library/rvca-yearbook (accessed 21.10.2018).

Rossiia uluchshila pozitsii v reitinge globalnoi konkurentosposobnosti [Russia has improved its position in the ranking of global competitiveness] (2018). Available at: https://ria.ru/economy/20181017/1530817839.html (accessed: 17.10.2018).

Sozdanie mezhdunarodnogo Fonda priamykh investitsii dlia podderzhki proizvoditelei uskorit reshenie prioritetnykh zadach po importozameshcheniiu [The creation of an international direct investment fund to support producers will accelerate the implementation of importsubstitution priorities](2017). Availableat: https://news.rambler.ru/other/37954184sozdanie-mezhdunarodnogo-fonda-pryamyh-investitsiy-dlya-podderzhki-proizvoditeleyuskorit-reshenie-prioritetnyh-zadach-po-importozamescheniyu/ (accessed: 2.3.18) 
$S \& P$ povyisilo kreditnyi reiting $R F$ do investitsionnogo urovnia $[S \& P$ raised the credit rating of the Russian Federation to the investment level] (2018). Available at: https://ria.ru/economy/20180224/1515209815.html (accessed: 24.02.2018).

Uspeshnye investitsii s RFPI. Otkryvaia novuiu Rossiiu. Godovoi obzor 2016 [Successful investment with the RPEF. Opening a new Russia. Annual review 2016] Available at: https://rdif.ru/data/file/broshures-successful-investments/RDIF\%20 $27482 \% 20$ AR2016 \%20RUS\%20Text\%20PUBLIC\%20Web\%20AW3.pdf (accessed: 07.03.2018).

Wright, Mike, John, Gilligan and Kevin, Amess (2009). The Economic Impact of Private Equity: What We Know and What We Would Like to Know. In Venture Capital, 11(1), 1-21.

\title{
Формирование проактивных стратегий китайских фондов прямых частных инвестиций на российском рынке корпоративного контроля
}

\author{
М.М. Мусатова, Л.И. Лугачева, Е.А. Соломенникова \\ Институт экономики и организации \\ промышленного производства СО РАН \\ Россия, 630090, Новосибирск, Академгородок, \\ пр. Академика Лаврентьева, 17
}

В статье рассмотрены гранииы и контуры возможного институционального поведения фондов прямых частных инвестиичй (PEF) в РФ в современных условиях. Анализируется трансформация отраслевых интересов со стороны РЕF к российским активам непубличных компаний в период экономической нестабильности. Дана релевантная оиенка изменению региональных аспектов взаимодействия РЕF и компанийрециипентов из России на фоне санкций и импортозамещзения, ичикличности рынка (PE). Представлены современные метрики китайских РЕF, осуществлен многоуровневый мониторинг действующих проектов китайских РЕF в экономике России. Проведен анализ последствий мультиагентских отношений PЕF и целевых компаний в России на фоне постепенного восстановления экономического роста страны. Обсуждается сложившийся и предпочитаемый формат участия инвесторов на рынке РЕ в условиях адаптации российской экономики к санкиионному режиму. Выявлень факторы, влияюшие на перспективы и динамику развития китайских PEF с инвестиционным мандатом на Россию. Обсуждаются механизмы институциональной поддержки расширения присутствия китайских РЕ на российском рынке корпоративного контроля.

Ключевые слова: прямые частные инвестиции, фонды прямых частных инвестиций, инвестиции, институциональная среда. 
Статья подготовлена по плану НИР ИЭОПП СО РАН в рамках проекта XI.172.1.3 (№ АAAA-A17-117022250130-8) «Теория и методология стратегического управления развитием высокотехнологичного бизнеса как базиса новой индустриализации» и проекта XL172.1.1. (ААAA-A17-117022250132-2) «Интеграция и взаимодействие отраслевых систем и рынков в России и ее восточных регионах: ограничения и новые возможности».

Научная специиальность: 08.00.14 - мировая экономика. 